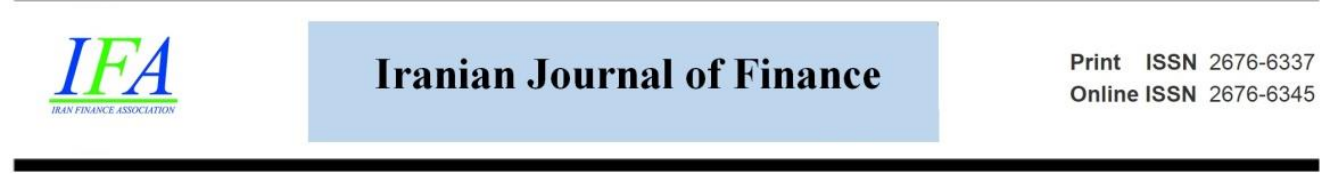

\title{
CEO Power, Corporate Risk-Taking, and the Role of Institutional Owners: Pieces of Evidence of Tehran Stock Exchange Market and Iran Fara Bourse
}

\section{Jamshid Bigdlo*}

*Corresponding Author, MSc. Department of Financial Management, Alborz University, Qazvin, Iran. (Email: jamshidbigdelo@gmail.com)

\section{Neda Bashiri}

PhD Candidate, Department of Business Administration, Payam Noor University of Tehran, Tehran, Iran. (Email: bashiri@ifb.ir)

\section{Reza Tehrani}

Prof., Department of Finance, Faculty of Management, University of Tehran, Tehran, Iran. (Email: rtehrani@ut.ac.ir)

\section{Fatemeh kheilkordi}

MSc. Department of Science in Economics Planning, Shahroud University of Technology. Tehran, Iran. (Email: f.kheilkordi@gmail.com)

Document Type: Original Article

Received: 2020/09/14 Accepted: 2021/03/28
2022, Vol. 6, No. 1. 117-141.

Published: 2022/02/09

\begin{abstract}
"Corporate governance" includes mechanisms to monitor CEO's performance to assure efficient decision adoption and maximize firm value. One of the most effective aspects of firm performance is the degree of risk-taking. This study investigates the relationship between CEO power and institutional ownership with risk-taking behavior of member firms of Tehran Stock Exchange and Iran Fara Bourse during 2010-2019 by utilizing quintile regression. According to
\end{abstract}


the results, by the increase of CEO's power and the company's benefit from powerful managers, the company risk (total risk and systemic risk) will decrease. As a result, managers are eager to safeguard their reputation as expert decision-makers and, as a result, they try to reduce company risk. In addition, the existence of institutional ownership among the shareholders of the company will reduce the risk, which can be referred to in the agency theory. Also, if the impact of these two variables is considered together, the risk will increase significantly. This very fact reflects the exercise of the power and influence of institutional owners. As a result, large shareholders have a supervisory role in the discipline of managers, but despite their impact on the relationship between managers' power and corporate risk, they do not alter the main negative relationship.

JEL Classification: G10, G30, G32, G34

Keywords: CEO power, institutional ownership, risk-taking, Exercising influence and power

DOI: https://doi.org/ 10.30699/IJF.2021.232129.1131 Publisher: Iran Finance Association Copyright: author(s) Type of License: Creative Commons License (CC-BY 4.0)

\section{Introduction}

Risk is an integral part of all business activities and its effective management not only helps firms to prevent financial problems and capital budgeting but improves the decision-making process. In fact, risk-taking has an important role in maintaining the competitive advantage of the firms and can lead them to economic growth. In a competitive setting, firms follow different strategies so that they can increase their shares in the market and create obstacles for others to enter. Strategy adoption requires various levels of risk acceptance and affects firms risk-taking differently. While certain business strategy adoptions will reduce firm vulnerability against macro-economic volatility and help firm systematic risk, on the other hand, the mentioned strategies can help to increase firm-specific risk, as well (Nguyen, 2011).

In certain organizations, the CEO takes all important decisions, while in other organizations, the final decisions are the result of group decision making which includes the CEO and other managers. Group decision making and organizational theory indicate that individual decisions have more risk-taking features while the results of group decision making are less riskier due to 
diversity of thoughts. Therefore, it is expected that in organizations in which the final result is the product of CEO judgement, the results lead to more risks. Given that, such a case highly depends on the influence of the CEO on the decision-making process (Liu \& Jiraporn, 2010).

Given the stated matters, by investigating the relationship between CEO power and institutional owners more accurately, this study attempts to answer the following question: "what relationship exists between CEO power and institutional ownership with firms risk-taking behavior?"

It is worth mentioning that regarding the topic under investigation, studies have been conducted, but given the investigations, it became obvious that limited foreign studies have been conducted by considering key variables for formulating CEO power and investigating its relationship with the firm risktaking behavior. Also, no similar study has been conducted in Iran so far and the present study is leading research in this regard. Therefore, the results of the present study in addition to filling the research gap in this domain can be beneficial to the decision making process of investors, creditors and other stakeholders. Along with investigating the above issue, this study is structured below: Section 2 investigates the conducted studies regarding the research topic. In section 3 we deal with research methodology and designing questions and models. In section 4, we answer the study question by using data analysis and estimating study models. In section 5 we present the conclusions and recommendations to develop the study for future research.

\section{Literature Review}

In order to be influential and effective, leaders need various instruments. power is one of their efficient tools. What matters the most in leadership, is the process of exerting power on others. The way to use influence and power is called the " leadership style". Influencing others is realized by creating a powerful image and creating this image entails accessing power resources. Most large shareholders have a lot of financial resources and fiducial responsibility to their clients. The existence of large shareholders assure minority shareholders that disclosed information by firms clearly show the financial situation of the firms and their wealth is being protected against management manipulations( Ayazi \& Eslami, 2019). Therefore, due to the amount of their shareholding, large shareholders have more motivation to monitor CEOs and have more power to make influential decisions. Also, they can affect the operational decisions of the firms by monitoring managers and help to the betterment of investment level and reduction of resource waste 
(Becker, Cronqvist \& Fahlenbrach, 2011).

On the other hand, the separation of CEO position and board of directors is a requirement of an efficient corporate governance system and causes independent and proper assessment of CEOs by the board of directors and improvement of monitoring and supervision mechanisms in the firm (La Porta, Lopez-de-Silanes \& Shleifer, 1999). On the contrary of the mentioned arguments regarding disagreement of CEO duality, a new branch of literature will be shaped which contends that separation of responsibilities causes reduction of the decision-making process of the CEOs and their disconformity with the board which weakens firm performance (Malekian \& Shayeste Mand, 2016).

CEO tenure is of other effective factors on CEO position and disturbing power balance in the board of directors. The longer tenure period will lead to a more stabilized position and more power in the decision-making process and less efficient monitoring by the board of directors. Therefore, if there is no proper alignment between CEO and shareholders benefits, the undesirable effects of agency problems will arise and investors benefits will be at risk (Malekian \& Shayeste mand, 2016). Also, from the perspective of agency theory, non-executive directors in boards and their monitoring function as independent bodies will help to reduce conflict of interest between shareholders and CEOs in board meetings. Non-executive managers judge CEOs decisions unbiasedly. Thus, by having expertise, independence and legal power, boards will be an efficient potential mechanism (Marrakchi, Jean \& Lucie, 2004). Women as members of the board tend to choose less risk-taking premiums comparing men who are more risk-takers. In fact, psychological and experimental literature have pieces of evidence of gender differences in risk tolerance and prominence (Bahrami, 2017). Unexperienced members in accounting and financial knowledge have fewer skills in discovering financial reporting problems. Therefore, an experienced member will cause awareness in other members (Nikbakht, Seyedi, \& Hashem Alhosseini, 2010). Following, certain foreign and inside studies dealing directly or indirectly with the present study will be mentioned.

In research, Pathan (2009) deals with an efficient board, CEO power and bank risk-taking behavior. According to the results of this study, boards of banks, especially small banks influence positively on banks risks. On the contrary, CEO power (CEO power to control board decisions) negatively influences banks to risk-taking behavior.

Abbasi \& Ahmadi (2011) investigated the relationship between 
governance and institutional investors in boards with the firm value. In order to analyze data and test hypotheses, multiple linear regression was used during 2001-2009 in the Tehran stock exchange market. The results indicate a significant and positive relation between institutional ownership and the degree of institutional investors presence in boards and firm value.

Abdul Rahman \& Zaki Nik (2011) investigated the effect of board characteristics on earnings management and risks during 2003- 2009 in the Malaysian stock market. The criterion of board characteristics in this study includes financial knowledge, number of meetings, non-duality of the roles, board composition, and the size of the board. According to the results of this study, CEO duality has a significant effect on earnings management reduction and risk reduction comparing other variables.

In a study for evaluating the level of risk-taking behavior, Mc Nulty, Florackis \& Armrod (2012) used a different criterion. They considered lowrisk firms as firms with high cash and cash equivalents during financial crises and high-risk firms as those who used cash reserves immediately. According to their results, there is a direct relationship between board size and firm risktaking behavior. On one hand, the number of non-executive managers and risk committee has no significant relationship with risk-taking behavior. Also, risktaking behavior will be reduced while executive membership is significantly higher than non-executive membership on board.

Chen \& Zheng (2014) investigated CEO responsibility and firms risktaking behavior in the S\&P index from 1992 to 2006. According to their results, CEO tenure has a positive effect on firm risk-taking.

Eling \& Marek (2014) investigated the relationship between corporate governance and the risk-taking of insurance firms in England and Germany. According to their results, there is a reverse relationship between governance components, e.g. CEO compensation, non-executive members and the number of meetings, with risk-taking.

Nikbakht \& Taheri (2014) research investigated the relationship between corporate governance mechanisms and systematic risk in the Tehran stock exchange market during 2004-2011. The results indicate that there is a significant relationship between the percentage of institutional shareholders who are a component and mechanism of corporate governance and systematic risk. Also, there is no relationship between the percentage of non-executives and systematic risk in general and other levels of the firm.

Nikpour (2014) investigated the relationship between corporate 
governance and financial, operational and environmental risk in accepted firms in the Tehran stock exchange market. The results indicated that there is no significant relationship between certain corporate governance indices (e.g. board size, the proportion of non-executive managers and the number of board meetings) with financial, operational and environmental risk but there is a significant relationship between firms with strong and weak governance.

Serfling (2014) in a study examined CEO age and risk-taking of the firm policy. According to the results of this study, CEO age can have a significant effect on firm risk-taking behavior and performance.

Toutchi (2014) investigated the effect of board diversity on financial reporting quality in accepted firms of the Tehran stock exchange market during 2009-2013. The results indicate that there is a positive and significant relationship between board size and board independence with financial reporting quality and there is a positive and significant relationship between financial knowledge of board and firms risk and there is no significant relationship between boards field of studying and their occupational background and their financial knowledge with financial reporting quality. Also, there is no relationship between board size and board independence and their field of studying and their occupational background with firm risk-taking behavior.

In a study, Haider \& Fang (2016) investigated the board size, ownership concentration and future risk of the firm. They found that when future price volatility and future cash flows are measured, board size will have a relation with the future risk. Second, large shareholders impress management decisions about future risk, regardless of board size. Third, the moderating role of ownership concentration in state and non-state firms is trivial.

In a study, Mahmood Abadi \& Zamani (2016) by focusing on corporate governance mechanisms investigated the relationship between firms risk-taking behavior and their financial performance in the Tehran stock exchange market during 2005-2012. The results indicate that the firms' risk-taking extent has a positive and significant relationship with their financial performance. The percentage of independent members of the board has a negative and significant effect on the extent of risk-taking but the percentage of institutional shareholders ownership and the number of the board has no significant relationship with the extent of risk-taking. Regarding the effect of board structure and institutional ownership on the relationship between risk-taking and financial performance, the results indicated that independence, size, and the percentage of institutional ownership of a firm has a positive effect on the 
relationship between risk-taking behavior and financial performance which supports this relationship.

Malekian \& Shayeste Mand (2016) investigated the effect of corporate governance managerial mechanisms, e.g. board and CEO characteristics on risk-taking of the member firms during 2008-2013. According to their results, the size and independence of the board and CEO influence is effective on firms risk-taking behavior but there is no relationship between CEO tenure and the duality of role and risk-taking.

In a study, Bahrami (2017) investigated the relationship between board gender and capital allocation efficiency with the risk-taking behavior of the accepted firms in the Tehran stock exchange market during 2013- 2016. The results indicate that there is no significant relationship between women CEOs in boards and efficiency of capital allocation with the risk-taking behavior of the examined firms.

In a study, Parvan, Ramzanpoor and Gholizade (2017) investigated the effect of corporate governance mechanisms on the risk-taking behavior of the accepted firms of the Tehran stock exchange market. Corporate governance mechanisms include a percentage of institutional shareholders of a firm, ownership concentration, CEO tenure and CEO duality. The results indicate a positive and significant relationship between ownership concentration, CEO tenure and dependent variables, e.g. financial and cash flow risk. The results of the mentioned study do not support a significant relationship between CEO duality and financial and cash flow risk.

In a study, Haider and Fang (2018) investigated CEO power, firms risktaking behavior and the role of large shareholders. Their results indicated that CEO power has a negative relationship with firm risk-taking behavior. Second of all, large shareholders influence this relation significantly. But the initial negative relationship between CEO power and firm risk-taking behavior is not altered. Also, the relationship between CEO power and firms risk-taking behavior is different in state and non-state firms.

In a study, Ayazi \& Eslami (2019) investigated the relationship between CEO power and risk-taking behavior of the accepted firms in the Tehran stock exchange market during 2012- 2017. According to their results, there is a significant relationship between $\mathrm{CEO}$ power and the risk-taking behavior of a firm. 


\section{Research Methodology and Research Findings}

The present study is applicable in terms of purpose and descriptive in terms of nature and methodology since it investigates the relationship between CEO power and institutional ownership with the risk-taking behavior of accepted firms of the Tehran stock exchange market. Data were collected daily, monthly and annually by using the Codal site and Rahavard Novin software. In order to classify and analyze data, Excel, Eviews 8 software and the quintile regression method were used for model fitness. ${ }^{1}$

Accepted firms in the Tehran stock exchange market were considered as statistics population. In order to sample, a purposeful sampling method (systematic removal) was utilized. For this purpose, all firms of statistics population with the following qualifications were chosen as a sample and the rest were deleted:

- They should be accepted in Tehran Stock Exchange and Iran Fara Bourse before 2010 ends.

- Their finical period shall end on March $19^{\text {th }}$.

- No financial change shall occur during the study period (2010-2019).

- Their required information and data shall be accessible in all investigated years in the financial year-end.

- During the investigation period, the symbol of the firm shall not be pending over 4 months each year, also during each month under investigation, trading days shall be more than or equal to 9 days and shall not be a member of the UTP Market (Red) of Fara Bourse. 2

By applying the above-mentioned conditions from accepted firms in Tehran Stock Exchange and Iran Fara Bourse, 107 firms were selected as statistic samples in this research (Refer to appendix).

\section{Research model and variables}

In the present study, according to Hideger \& Fang (2018) CEO power was obtained by applying the principal component analysis (PCA) technique. In

\footnotetext{
${ }^{1}$ Because simultaneous attention to the general set of estimated quintiles will provide a more comprehensive idea regarding the effect of auxiliary variables on location, scale and the form of distribution of response variable.

${ }^{2}$ With the change in the rules, UTP Market (j) was removed from the OTC market list, and UTP Market (Red) has been used instead of UTP Market (j) in research. Since there are just three trading days in UTP Market (j) of Fara Bourse during the week, the number of observations of the member firms is half of the member firms of the statistics population and is not comparatively strong, as a result, it is ignored in statistics population.
} 
order to investigate it accurately, 3 indices of risk were calculated as risk developing variables, then 3 regression models were used, such that in model 1 , the relationship between CEO power and institutional ownership with general risk of firms, and in model 2, the relationship between CEO power and institutional ownership with a specific risk of the firms and in model 3, the relationship between CEO power and institutional ownership with systematic risk of the firms were dealt.

$\llbracket$ Total Risk】_it $=\alpha \_0+\beta \_1$ CEOP_ $(\mathrm{i}, \mathrm{t}-1)+\beta_{-} 2$ 『Bord Size \_(i,t $1)+\beta \_3$ 『Indp. Directors \(i,t -1$)+$

$\beta_{-} 4$ 『Ownership Concentration》_(i, $\left.\mathrm{t}-1\right)+$

$\beta \_5$ 『Managment Shareholding】_(i, t - 1) $+\beta_{-} 6 \mathrm{ROA}_{-}(\mathrm{i}, \mathrm{t}-1)+$

$\beta \_7$ Leverage_(i, $\left.t\right)+\beta \_8$ Size $_{-}(i, t-1)+\beta_{-} 9$ Capex_$_{-}(i, t-1)+$

$\beta_{-} 10$ Cashflow_(i, t1 $)+\beta_{-} 11$ 『M/B】_(i, t - 1) + $\beta_{-} 12$ AGE_$_{-}(\mathrm{i}, \mathrm{t}-1)+$

$\beta_{-} 13$ 『CEOP_OWNERSHIP】_(i, t) +

$\beta_{-} 14$ 『CEOP_OWNERSHIP_SOE】_(i, t $)+\beta_{-} 15$ INDUSTRY_(i, t $)+\varepsilon_{-}(i, t)$

Specific Risk $_{i t}=\alpha \_0+\beta \_1$ CEOP_ $(i, t-1)+\beta \_2$ 『Bord Size \_ $(i, t-$ $1)+\beta_{-} 3 \quad$ 『Indp.Directors $\rrbracket \_(i, t-1)+$

$\beta_{-} 4 \llbracket$ Ownership Concentration $\rrbracket+(i, t-1)+$

$\beta \_5$ 『Managment Shareholding \_ $(i, t-1)+\beta_{-} 6 R O A_{-}(i, t-1)+$

$\beta_{-} 7$ Leverage $(i, t)+\beta \_8$ Size $(i, t-1)+\beta_{-} 9$ Capex_ $(i, t-1)+$

$\beta_{-} 10$ Cashflow $_{-}(i, t-1)+\beta_{-} 11 \rrbracket M / B \rrbracket \_(i, t-1)+\beta_{-} 12 A G E_{-}(i, t-$

$1)+\beta_{-} 13 \quad \llbracket C E O P_{-} O W N E R S H I P \rrbracket \_(i, t)+$

$\beta_{-} 14 \llbracket C E O P \_O W N E R S H I P \_S O E \rrbracket_{-}(i, t)+\beta_{-} 15 \operatorname{INDUSTRY}(i, t)+$

$\varepsilon_{-}(i, t)$

Systematic risk it

$$
\begin{aligned}
& =\alpha_{0}+\beta_{1} \text { CEOP }_{i, t-1}+\beta_{2} \text { Bord Size }_{i, t-1}+\beta_{3 \text { Indp.Directors }}{ }_{i, t-1} \\
& +\beta_{4} \text { Ownership Concentration }_{i, t-1} \\
& +\beta_{5} \text { Managment Shareholding }_{i, t-1}+\beta_{6} \text { ROA }_{i, t-1} \\
& +\beta_{7} \text { Leverage }_{i, t}+\beta_{8} \text { Size }_{i, t-1}+\beta_{9} \text { Capex }_{i, t-1} \\
& +\beta_{10} \text { Cashflow }_{i, t-1}+\beta_{11} \frac{M}{B_{i, t-1}}+\beta_{12} \text { CEOP }_{\text {OWNERSHIP }} i, t \\
& +\beta_{14} \text { CEOP }_{\text {OWNERSHIPSOE }}+, t \\
& +\beta_{15} \text { INDUSTRY }_{i, t}+\varepsilon_{i, t}
\end{aligned}
$$


The definition and calculation method of the variables in the present study has been presented in table 1 .

Table 1. Variable definition

\begin{tabular}{|c|c|}
\hline variable & definition \\
\hline Total risk & The standard deviation of stock daily return for each year \\
\hline Specific risk & $\begin{array}{l}\text { The residual standard deviation of the Three-factor model by } \\
\text { Fama \& French will be clarified in the following section. }\end{array}$ \\
\hline Systematic risk & Total risk minus the specific risk \\
\hline CEOP & $\begin{array}{l}\text { The principal component analysis will be clarified in the } \\
\text { following section. }\end{array}$ \\
\hline Board size & The number of board of directors. \\
\hline Indp. Directors & $\begin{array}{c}\text { The number of non-executive managers divided by executive } \\
\text { managers }\end{array}$ \\
\hline Ownership concentration & $\begin{array}{c}\text { The share percentage belonging to } 5 \text { blockholders with over } 5 \% \\
\text { ownership }\end{array}$ \\
\hline $\begin{array}{l}\text { Management } \\
\text { shareholding }\end{array}$ & Percentage of shares belonging to CEO \\
\hline ROA & Net profit divided by asset \\
\hline Leverage & Total debt divided by total asset \\
\hline Size & natural logarithm of Assets \\
\hline CAPEX & (amortization plus fixed assets) divided by total assets. \\
\hline Cash flow & $\begin{array}{l}\text { (operational earnings plus amortization minus tax) divided by } \\
\text { income }\end{array}$ \\
\hline Market-to-Book & Market value divided by book value \\
\hline AGE & the logarithm of the years since Firm establishment \\
\hline SOE & $\begin{array}{l}\text { If the government owns } 30 \% \text { of the shares, it equals } 1 \text {, otherwise } \\
0 .\end{array}$ \\
\hline Ceop*ownership & CEO power multiplied by institutional ownership \\
\hline Ceop*ownership*seo & CEO power multiplied by institutional ownership and state firms. \\
\hline Industry & Two-digit industry code \\
\hline
\end{tabular}

CEO power: In order to calculate this variable by developing the studies of Haiderger \&Fang (2018) and by using the PCA technique, 13 components were used to develop CEO power. The variables are presented in Table 2. 
CEO Power, Corporate Risk-Taking, and the Role of Institutional...

Table 2. components used for calculating CEO power

\begin{tabular}{|c|c|c|}
\hline $\begin{array}{c}\text { Power } \\
\text { structure }\end{array}$ & Variables & Definition \\
\hline \multirow{3}{*}{$\begin{array}{l}\text { Structural } \\
\text { power }\end{array}$} & Duality & If CEO and chairman are the same $=0$, otherwise 1 . \\
\hline & $\begin{array}{c}\text { Inside } \\
\text { management }\end{array}$ & If CEO is on board $=0$, otherwise 1. \\
\hline & Independence & $\begin{array}{l}\text { If the number of non-executive managers is higher than } \\
\text { the average of industry }=1 \text {, otherwise } 0 .\end{array}$ \\
\hline \multirow{3}{*}{$\begin{array}{l}\text { Ownership } \\
\text { power }\end{array}$} & $\begin{array}{c}\text { CEO } \\
\text { shareholding }\end{array}$ & If CEO is a shareholder $=1$, otherwise 0. \\
\hline & $\begin{array}{c}\text { Large } \\
\text { shareholders }\end{array}$ & $\begin{array}{l}\text { If shareholders ownership is higher than average of } \\
\text { industry }=1 \text {, otherwise } 0 \text {. }\end{array}$ \\
\hline & $\begin{array}{l}\text { Institutional } \\
\text { ownership }\end{array}$ & $\begin{array}{l}\text { If among percentage shareholders, percentage of legal } \\
\text { entity is higher than natural person }=1 \text {, otherwise } 0 .\end{array}$ \\
\hline \multirow{3}{*}{$\begin{array}{l}\text { Expertise } \\
\text { power }\end{array}$} & Expertise & $\begin{array}{l}\text { If CEO field of study is related to the job }=1 \text {, otherwise } \\
0 .\end{array}$ \\
\hline & Education & If CEO has a master degree or above $=1$, otherwise 0 . \\
\hline & Analytical skills & $\begin{array}{l}\text { If the CEO field of studying is financial and economic } \\
\text { sciences }=1 \text {, otherwise } 0 .\end{array}$ \\
\hline \multirow{2}{*}{$\begin{array}{c}\text { Credit or } \\
\text { influencing } \\
\text { power }\end{array}$} & Experience & If CEO tenure is above industry average $=1$, otherwise 0 . \\
\hline & Outside service & If CEO serves on other firms board=1, otherwise 0 . \\
\hline \multirow{2}{*}{ Social power } & Tenure duration & If CEO tenure is over one year $=1$, otherwise 0 . \\
\hline & Gender & If CEO is a man 1 , otherwise 0. \\
\hline
\end{tabular}

It is worth mentioning that the required data for calculating CEO power have been extracted from the notes of the financial statements in different years and certain cases, they have been compared with the available data in financial statement notes of other available firms in the same industry.

Specific risk: to calculate this variable, Fama \&French three-factor model (model 4) was fitted monthly by using daily data and following that, the residuals were extracted. In the end, standard deviations of the residuals were calculated for each year and were considered as a specific risk.

$$
\text { Relation 4) } R_{i t}-R_{f}=\alpha_{i}+\beta_{i}\left(R_{t}-R_{f}\right)+\beta_{i}(H M L)+\beta_{i}(S M B)+\varepsilon_{i, t}
$$

Where $\left(R_{i}\right)$ is the stock monthly return of the considered firm during the investigation period, $\left(\mathrm{R}_{\mathrm{f}}\right)$ is the risk-free return which equals a one-year deposit return rate announced by the central bank of the Islamic Republic of Iran, $\left(R M_{t}\right)$ is the monthly return during the period under study, (HML) is the excess return of value stocks to growth stock, (SMB) is the historic return of stock excess with low capital comparing high capital. 


\section{Data analysis and estimation models}

Descriptive statistics: before data analysis, descriptive statistics of the variables, e.g. mean, standard deviation, median, maximum and minimum are presented in table 2 .

Table 3. descriptive statistics

\begin{tabular}{|c|c|c|c|c|c|c|c|}
\hline variable & Mean & $\begin{array}{c}\text { Media } \\
\text { n }\end{array}$ & $\begin{array}{c}\text { Maximu } \\
\text { m }\end{array}$ & $\begin{array}{c}\text { Minimu } \\
\text { m }\end{array}$ & $\begin{array}{l}\text { Std. } \\
\text { Dev }\end{array}$ & $\begin{array}{c}\text { Skewnes } \\
\text { s }\end{array}$ & $\begin{array}{c}\text { Kurtosi } \\
\text { s }\end{array}$ \\
\hline Total Risk & 2.48 & 2.48 & 5.826 & 0.421 & 0.875 & 0.627 & 4.078 \\
\hline $\begin{array}{c}\text { Idiosyncratic } \\
\text { Risk }\end{array}$ & 0.135 & 0.121 & 0.509 & 0.034 & 0.067 & 1.614 & 6.983 \\
\hline $\begin{array}{c}\text { Systematic } \\
\text { Risk } \\
\end{array}$ & 2.345 & 2.338 & 5.688 & 0.368 & 0.843 & 0.653 & 4.163 \\
\hline Ceop & 0.000 & -0.258 & 5.089 & -2.387 & 1.393 & 0.907 & 3.303 \\
\hline Board Size & 5.067 & 5 & 8 & 3 & 0.379 & 4.149 & 29.651 \\
\hline $\begin{array}{c}\text { Indp. } \\
\text { Directors }\end{array}$ & 0.666 & 0.6 & 1 & 0.000 & 0.177 & -0.396 & 3.119 \\
\hline $\begin{array}{c}\text { Ownership } \\
\text { Concentratio } \\
n\end{array}$ & 0.753 & 0.81 & 0.982 & 0.000 & 0.186 & -1.284 & 4.424 \\
\hline $\begin{array}{l}\text { Management } \\
\text { Shareholding }\end{array}$ & 4.424 & 0.000 & 91.314 & 0.000 & $\begin{array}{c}15.90 \\
9\end{array}$ & 3.975 & 18.181 \\
\hline ROA & $\begin{array}{c}12.55 \\
5\end{array}$ & 10.656 & 63.134 & -58.331 & $\begin{array}{c}14.02 \\
1\end{array}$ & 0.415 & 4.91 \\
\hline Leverage & 0.57 & 0.586 & 2.665 & 0.013 & 0.22 & 1.055 & 12.863 \\
\hline Size & $\begin{array}{c}14.28 \\
2 \\
\end{array}$ & 14.11 & 19.774 & 10.952 & 1.498 & 0.756 & 3.95 \\
\hline CAPEX & 0.045 & 0.023 & 0.903 & -0.434 & 0.089 & 3.866 & 28.55 \\
\hline Cash Flows & 0.234 & 0.184 & 3.724 & -1.313 & 0.275 & 2.586 & 33.926 \\
\hline $\begin{array}{c}\text { Market-to- } \\
\text { Book } \\
\end{array}$ & 1.383 & 1.066 & 12.5 & 0.032 & 1.203 & 2.989 & 19.016 \\
\hline Ln_age & $\begin{array}{c}38.41 \\
1 \\
\end{array}$ & 41 & 67 & 6 & $\begin{array}{c}14.73 \\
1 \\
\end{array}$ & -0.246 & 1.859 \\
\hline
\end{tabular}

Source: research findings

Regrading table 4 and the statistics of general, specific risk and systematic risk, it can be mentioned that systematic risk shapes the majority of general firm risk which is the result of political and exerted sanction on Iran during years and by considering that general risk has been calculated from the standard deviation of each share, it can be said that outliers and positive skewness and kurtosis of the distribution can be the result of the high volatility of certain firms for different reasons e.g. inflation, speculation etc. 
A normality test: In order to use quintile regression, the non-normality of the data must be proved first. As you can see in table 4, given the significance of Jarque- Bera statistics in all variables, the null hypothesis which indicated normality, will be rejected. Therefore, all variables have a non-normal distribution.

Table 4. normality test of the variables.

\begin{tabular}{|c|c|c|c|}
\hline variable & Jarque-Bera & Probability & Observations \\
\hline Total Risk & 109.761 & 0.000 & 963 \\
\hline Idiosyncratic Risk & 1054.776 & 0.000 & 963 \\
\hline Systematic Risk & 122.607 & 0.000 & 963 \\
\hline Ceop & 135.832 & 0.000 & 963 \\
\hline Board Size & 31229.082 & 0.000 & 962 \\
\hline Indp. Directors & 25.713 & 0.000 & 962 \\
\hline Ownership Concentration & 346.139 & 0.000 & 963 \\
\hline Management Shareholding & 11782.952 & 0.000 & 963 \\
\hline ROA & 173.977 & 0.000 & 963 \\
\hline Leverage & 4082.133 & 0.000 & 963 \\
\hline Size & 127.995 & 0.000 & 963 \\
\hline CAPEX & 28591.73 & 0.000 & 963 \\
\hline Cash Flows & 39450.001 & 0.000 & 963 \\
\hline Market-to-Book & 11726.881 & 0.000 & 963 \\
\hline Age & 160.745 & 0.000 & 963 \\
\hline
\end{tabular}

Source: research findings

Given the stated issues, the best method to estimate the model is quintile regression since in this method quintiles are used rather than means.

Static test: In econometrics, the static test is used to avoid regressions with fake relations. If data are not static, it is not possible to use them in regression and rely on the results. To measure static variables, Levin, Lin \& Chu t, Im, Pesaran and Shin, ADF- Fisher and PP-Fisher tests were used. 
Iranian Journal of Finance, 2021, Vol. 6, No. 1 (Bigdlo, J.)

Table 5. static test results

\begin{tabular}{|c|c|c|c|c|c|c|c|c|}
\hline \multirow{2}{*}{ variable } & \multicolumn{2}{|c|}{$\begin{array}{c}\text { Levin, Lin \& } \\
\text { Chu t }\end{array}$} & \multicolumn{2}{c|}{$\begin{array}{c}\text { Im, Pesaran } \\
\text { and Shin W- } \\
\text { stat }\end{array}$} & \multicolumn{2}{c|}{$\begin{array}{c}\text { ADF - Fisher } \\
\text { Chi-square }\end{array}$} & \multicolumn{2}{c|}{$\begin{array}{c}\text { PP - Fisher } \\
\text { Chi-square }\end{array}$} \\
\cline { 2 - 9 } & Statistic & Prob & Statistic & Prob & Statistic & Prob & Statistic & Prob \\
\hline Total Risk & -10.094 & 0.000 & -3.489 & 0.000 & 295.773 & 0.000 & 605.391 & 0.000 \\
\hline $\begin{array}{c}\text { Idiosyncratic } \\
\text { Risk }\end{array}$ & -15.806 & 0.000 & -5.751 & 0.000 & 370.241 & 0.000 & 668.601 & 0.000 \\
\hline Systematic Risk & -10.783 & 0.000 & -3.698 & 0.000 & 304.378 & 0.000 & 611.833 & 0.000 \\
\hline Ceop & 9.995 & 1.000 & -0.295 & 0.384 & 251.352 & 0.033 & 439.188 & 0.000 \\
\hline Board Size & -3.351 & 0.000 & -1.511 & 0.065 & 30.994 & 0.029 & 78.781 & 0.000 \\
\hline Indp. Directors & -127.32 & 0.000 & -12.588 & 0.000 & 258.421 & 0.000 & 391.270 & 0.000 \\
\hline $\begin{array}{c}\text { Ownership } \\
\text { Concentration }\end{array}$ & -4.134 & 0.000 & -6.239 & 0.000 & 400.609 & 0.000 & 780.627 & 0.000 \\
\hline $\begin{array}{c}\text { Management } \\
\text { Shareholding }\end{array}$ & -564.80 & 0.000 & -175.70 & 0.000 & 183.376 & 0.000 & 338.944 & 0.000 \\
\hline RoA & -34.093 & 0.000 & -7.054 & 0.000 & 397.633 & 0.000 & 538.050 & 0.000 \\
\hline Leverage & -11.710 & 0.000 & -3.562 & 0.000 & 312.515 & 0.000 & 636.967 & 0.000 \\
\hline Size & -40.155 & 0.000 & -4.456 & 0.000 & 297.791 & 0.000 & 435.083 & 0.000 \\
\hline CAPEX & -7.420 & 0.000 & -6.996 & 0.000 & 411.049 & 0.000 & 1100.39 & 0.000 \\
\hline Cash Flows & -18.287 & 0.000 & -4.081 & 0.000 & 338.501 & 0.000 & 495.446 & 0.000 \\
\hline Market-to-Book & -13.677 & 0.000 & -4.305 & 0.000 & 342.885 & 0.000 & 576.107 & 0.000 \\
\hline Age & -70.258 & 0.000 & -519.70 & 0.000 & 1977.80 & 0.000 & 1971.01 & 0.000 \\
\hline
\end{tabular}

Source: research findings

According to table 5, investigating the statistics value and probabilities indicate that all variables are static. Therefore, it should be mentioned that regarding the results of Im, Pesaran and Shin tests for CEO power and board size, we should rely on the results of other tests, because according to the results, other tests used for the above-mentioned variables are static.

Estimating models: as was mentioned before, in this study, we seek to investigate and analyze the relationship between CEO power and institutional ownership with the change of risk behavior of firms and quintile regression has been used to estimate models. It is worth explaining that when quintile regression is approximated $10 \%$, the effect of variables will be tested on periods or firms with conservative policies in risk management. Accordingly, simply say, $10 \%, 30 \%, 50 \%, 70 \%, 90 \%$ quintiles are labeled as firms with very low, low, average, high, and very high risk, respectively. 
CEO Power, Corporate Risk-Taking, and the Role of Institutional...

Table 6. fitness results of model 1( dependent variable: general risk of the firm)

\begin{tabular}{|c|c|c|c|c|c|}
\hline Quintile regression & $\% 10$ & $\% 30$ & $\% 50$ & $\% 70$ & $\% 90$ \\
\hline Variable & $\begin{array}{c}\text { Coefficient } \\
(\mathrm{t}- \\
\text { Statistic) }\end{array}$ & $\begin{array}{c}\text { Coefficient } \\
\text { (t- } \\
\text { Statistic) }\end{array}$ & $\begin{array}{c}\text { Coefficient } \\
\text { (t- } \\
\text { Statistic) }\end{array}$ & $\begin{array}{c}\text { Coefficient } \\
(\mathrm{t}- \\
\text { Statistic) }\end{array}$ & $\begin{array}{c}\text { Coefficient } \\
\text { (t- } \\
\text { Statistic) }\end{array}$ \\
\hline $\mathrm{C}$ & $\begin{array}{c}4.089 \\
(6.656)^{* * *}\end{array}$ & $\begin{array}{c}4.109 \\
(7.479)^{* * *}\end{array}$ & $\begin{array}{c}4.383 \\
(10.343)^{* * *}\end{array}$ & $\begin{array}{c}4.268 \\
(6.811)^{* * * *}\end{array}$ & $\begin{array}{c}3.352 \\
(2.808)^{* * *}\end{array}$ \\
\hline Ceop & $\begin{array}{c}-0.079 \\
(-1.583)^{*}\end{array}$ & $\begin{array}{c}-0.113 \\
(-3.563)^{\text {*** }}\end{array}$ & $\begin{array}{c}-0.095 \\
(-3.217)^{* * *}\end{array}$ & $\begin{array}{c}-0.075 \\
(-2.438)^{* *} \\
\end{array}$ & $\begin{array}{c}-0.176 \\
(-3.072)^{* * *} \\
\end{array}$ \\
\hline Board size & $\begin{array}{c}-0.025 \\
(-0.287)\end{array}$ & $\begin{array}{c}-0.033 \\
(-0.322)\end{array}$ & $\begin{array}{c}-0.02 \\
(-0.325)\end{array}$ & $\begin{array}{c}-0.013 \\
(-0.161)\end{array}$ & $\begin{array}{c}0.004 \\
-0.033\end{array}$ \\
\hline Indp. Directors & $\begin{array}{c}-0.034 \\
(-0.113)\end{array}$ & $\begin{array}{l}0.052 \\
-0.265\end{array}$ & $\begin{array}{c}0.12 \\
-0.81\end{array}$ & $\begin{array}{c}-0.042 \\
(-0.215)\end{array}$ & $\begin{array}{c}-0.373 \\
(-0.734)\end{array}$ \\
\hline $\begin{array}{l}\text { Ownership } \\
\text { concentration }\end{array}$ & $\begin{array}{c}-0.879 \\
(-3.616)^{\text {*** }}\end{array}$ & $\begin{array}{c}-0.638 \\
(-3.482)^{\text {*** }}\end{array}$ & $\begin{array}{c}-0.744 \\
(-5.434)^{* * *}\end{array}$ & $\begin{array}{c}-0.473 \\
(-2.936)^{\text {*** }}\end{array}$ & $\begin{array}{c}-0.273 \\
(-0.657)\end{array}$ \\
\hline $\begin{array}{l}\text { Management } \\
\text { shareholding }\end{array}$ & $\begin{array}{c}0.006 \\
(3.315)^{* * * *}\end{array}$ & $\begin{array}{c}0.003 \\
(1.759)^{\text {** }} \\
\end{array}$ & $\begin{array}{c}0.002 \\
(1.434)^{*}\end{array}$ & $\begin{array}{c}0 \\
-0.209 \\
\end{array}$ & $\begin{array}{c}-0.001 \\
(-0.150)\end{array}$ \\
\hline ROA & $\begin{array}{c}-0.013 \\
(-2.375)^{* *}\end{array}$ & $\begin{array}{c}-0.015 \\
(-4.249)^{\text {*** }}\end{array}$ & $\begin{array}{c}-0.013 \\
(-3.010)^{* * *}\end{array}$ & $\begin{array}{c}-0.01 \\
(-2.434)^{* *}\end{array}$ & $\begin{array}{c}-0.013 \\
(-1.517)^{*}\end{array}$ \\
\hline Leverage & $\begin{array}{c}0.608 \\
(1.588)^{*}\end{array}$ & $\begin{array}{c}0.497 \\
(2.306)^{* *}\end{array}$ & $\begin{array}{c}0.531 \\
(2.493)^{* *}\end{array}$ & $\begin{array}{c}0.503 \\
(2.623)^{* * *}\end{array}$ & $\begin{array}{c}0.957 \\
(3.000)^{\text {*** }}\end{array}$ \\
\hline Size & $\begin{array}{c}-0.044 \\
(-1.397)^{*}\end{array}$ & $\begin{array}{c}-0.063 \\
(-2.056)^{* *}\end{array}$ & $\begin{array}{c}-0.073 \\
(-3.402)^{* * *}\end{array}$ & $\begin{array}{c}-0.083 \\
(-3.815)^{\text {*** }}\end{array}$ & $\begin{array}{c}-0.067 \\
(-1.567)^{*}\end{array}$ \\
\hline CAPEX & $\begin{array}{c}0.84 \\
(3.417)^{* * *}\end{array}$ & $\begin{array}{c}0.201 \\
-0.885\end{array}$ & $\begin{array}{c}-0.164 \\
(-0.796)\end{array}$ & $\begin{array}{c}-0.445 \\
(-1.641)^{*}\end{array}$ & $\begin{array}{c}0.337 \\
-0.456\end{array}$ \\
\hline Cash Flows & $\begin{array}{c}-0.116 \\
(-0.947)\end{array}$ & $\begin{array}{c}-0.109 \\
(-0.559)\end{array}$ & $\begin{array}{c}0.075 \\
-0.286\end{array}$ & $\begin{array}{c}0.098 \\
-1.241\end{array}$ & $\begin{array}{c}0.259 \\
-0.765\end{array}$ \\
\hline Market-to-Book & $\begin{array}{c}0.077 \\
-0.839 \\
\end{array}$ & $\begin{array}{c}0.067 \\
(1.634)^{*}\end{array}$ & $\begin{array}{c}0.129 \\
(2.950)^{* * *} \\
\end{array}$ & $\begin{array}{c}0.158 \\
(2.624)^{* * *}\end{array}$ & $\begin{array}{c}0.462 \\
(5.010)^{* * * *}\end{array}$ \\
\hline Age & $\begin{array}{c}-0.335 \\
(-4.302)^{* * *}\end{array}$ & $\begin{array}{c}-0.154 \\
(-2.568)^{* *}\end{array}$ & $\begin{array}{c}-0.124 \\
(-2.301)^{* *}\end{array}$ & $\begin{array}{c}-0.026 \\
(-0.475)\end{array}$ & $\begin{array}{c}0.171 \\
-1.311\end{array}$ \\
\hline Ceop*Ownership & $\begin{array}{c}0.171 \\
(2.859)^{* * *} \\
\end{array}$ & $\begin{array}{c}0.17 \\
(3.617)^{* * *} \\
\end{array}$ & $\begin{array}{c}0.14 \\
(3.727)^{* * *} \\
\end{array}$ & $\begin{array}{c}0.107 \\
(2.458)^{* *}\end{array}$ & $\begin{array}{c}-0.012 \\
(-0.200)\end{array}$ \\
\hline Ceop*Ownership*Soe & $\begin{array}{c}0.123 \\
(1.675)^{*}\end{array}$ & $\begin{array}{l}0.054 \\
-1.01 \\
\end{array}$ & $\begin{array}{r}0.048 \\
-0.987 \\
\end{array}$ & $\begin{array}{c}0.028 \\
-0.554 \\
\end{array}$ & $\begin{array}{c}0.093 \\
-0.894 \\
\end{array}$ \\
\hline Industry & $\begin{array}{c}-0.007 \\
(-1.464)^{*}\end{array}$ & $\begin{array}{c}-0.004 \\
(-1.585)^{*}\end{array}$ & $\begin{array}{c}-0.006 \\
(-2.872)^{* * *}\end{array}$ & $\begin{array}{c}-0.005 \\
(-2.384)^{\text {*** }}\end{array}$ & $\begin{array}{c}-0.006 \\
(-1.588)^{*}\end{array}$ \\
\hline Pseudo R-squared & 0.133 & 0.136 & 0.123 & 0.088 & 0.103 \\
\hline Adjusted R-squared & 0.118 & 0.12 & 0.107 & 0.072 & 0.087 \\
\hline Quasi-LR statistic & 104.008 & 170.916 & 192.293 & 125.09 & 72.296 \\
\hline Prob (Quasi-LR stat) & 0 & 0 & 0 & 0 & 0 \\
\hline
\end{tabular}


Iranian Journal of Finance, 2021, Vol. 6, No. 1 (Bigdlo, J.)

Table 7. fitness results of model2 (dependent variable: specific risk)

\begin{tabular}{|c|c|c|c|c|c|}
\hline Quintile regression & $\% 10$ & $\% 30$ & $\% 50$ & $\% 70$ & $\% 90$ \\
\hline Variable & $\begin{array}{c}\text { Coefficient } \\
(\mathrm{t}- \\
\text { Statistic) }\end{array}$ & $\begin{array}{c}\text { Coefficient } \\
(\mathrm{t}- \\
\text { Statistic) }\end{array}$ & $\begin{array}{c}\text { Coefficient } \\
\text { (t- } \\
\text { Statistic) }\end{array}$ & $\begin{array}{c}\text { Coefficient } \\
(t- \\
\text { Statistic) }\end{array}$ & $\begin{array}{c}\text { Coefficient } \\
(t- \\
\text { Statistic) }\end{array}$ \\
\hline $\mathrm{C}$ & $\begin{array}{c}0.103 \\
(3.657)^{* * * *}\end{array}$ & $\begin{array}{c}0.193 \\
(5.071)^{* * *}\end{array}$ & $\begin{array}{c}0.149 \\
(2.977)^{* * *}\end{array}$ & $\begin{array}{c}0.215 \\
(4.708)^{* * *}\end{array}$ & $\begin{array}{c}0.361 \\
(5.865)^{* * *}\end{array}$ \\
\hline Ceop & $\begin{array}{c}-0.005 \\
(-2.268)^{* *}\end{array}$ & $\begin{array}{c}-0.002 \\
(-0.684)\end{array}$ & $\begin{array}{c}-0.001 \\
(-0.216)\end{array}$ & $\begin{array}{c}-1.0 \mathrm{E}-06 \\
(-0.000)\end{array}$ & $\begin{array}{l}-0.002 \\
(-0.382)\end{array}$ \\
\hline Board size & $\begin{array}{l}-0.001 \\
(-0.320)\end{array}$ & $\begin{array}{l}-0.006 \\
(-0.929)\end{array}$ & $\begin{array}{c}0.003 \\
(0.360)\end{array}$ & $\begin{array}{c}0.005 \\
(1.047)\end{array}$ & $\begin{array}{c}-0.009 \\
(-1.466)^{*}\end{array}$ \\
\hline Indp. Directors & $\begin{array}{l}-0.003 \\
(-0.232)\end{array}$ & $\begin{array}{l}-0.001 \\
(-0.047)\end{array}$ & $\begin{array}{c}0.003 \\
(0.168)\end{array}$ & $\begin{array}{l}-0.010 \\
(-0.627)\end{array}$ & $\begin{array}{l}-0.033 \\
(-1.229)\end{array}$ \\
\hline $\begin{array}{l}\text { Ownership } \\
\text { concentration }\end{array}$ & $\begin{array}{c}-0.017 \\
(-1.293)\end{array}$ & $\begin{array}{c}-0.024 \\
(-2.195)^{* *}\end{array}$ & $\begin{array}{c}-0.022 \\
(-1.549)^{* *}\end{array}$ & $\begin{array}{c}-0.019 \\
(-1.060)\end{array}$ & $\begin{array}{l}-0.013 \\
(-0.528)\end{array}$ \\
\hline $\begin{array}{l}\text { Management } \\
\text { shareholding }\end{array}$ & $\begin{array}{l}6.2 \mathrm{E}-05 \\
(0.607)\end{array}$ & $\begin{array}{c}-2.6 \mathrm{E}-05 \\
(-0.239)\end{array}$ & $\begin{array}{l}0.0001 \\
(0.919)\end{array}$ & $\begin{array}{c}0.00010 \\
(0.656)\end{array}$ & $\begin{array}{c}-0.00020 \\
(-0.853)\end{array}$ \\
\hline ROA & $\begin{array}{c}-0.001 \\
(-1.322)\end{array}$ & $\begin{array}{c}-0.001 \\
(-3.233)^{* * *}\end{array}$ & $\begin{array}{c}-0.001 \\
(-2.597)^{* *}\end{array}$ & $\begin{array}{c}-0.001 \\
(-2.854)^{* * *}\end{array}$ & $\begin{array}{c}-0.002 \\
(-4.480)^{* * *}\end{array}$ \\
\hline Leverage & $\begin{array}{c}0.040 \\
(3.110)^{* * *}\end{array}$ & $\begin{array}{c}0.051 \\
(3.154)^{* * *}\end{array}$ & $\begin{array}{c}0.084 \\
(4.723)^{* * *}\end{array}$ & $\begin{array}{c}0.104 \\
(4.502)^{* * *}\end{array}$ & $\begin{array}{c}0.086 \\
(3.813)^{* * * *}\end{array}$ \\
\hline Size & $\begin{array}{c}-0.002 \\
(-1.711)^{*}\end{array}$ & $\begin{array}{c}-0.005 \\
(-3.100)^{\text {*** }}\end{array}$ & $\begin{array}{c}-0.005 \\
(-2.895)^{\text {*** }}\end{array}$ & $\begin{array}{c}-0.009 \\
(-4.095)^{\text {*** }}\end{array}$ & $\begin{array}{c}-0.015 \\
(-5.527)^{* * *}\end{array}$ \\
\hline & 0.012 & 0.008 & -0.003 & 0.021 & 0.103 \\
\hline CAPEX & (0.694) & (0.389) & $(-0.094)$ & $(0.613)$ & $(1.792)^{* *}$ \\
\hline Cash Flows & $\begin{array}{c}0.004 \\
(0.606)\end{array}$ & $\begin{array}{c}-0.002 \\
(-0.150)\end{array}$ & $\begin{array}{c}0.000 \\
(0.038)\end{array}$ & $\begin{array}{c}-0.003 \\
(-0.450)\end{array}$ & $\begin{array}{c}-0.019 \\
(-3.499)^{* * * *}\end{array}$ \\
\hline Market-to-Book & $\begin{array}{c}0.012 \\
(2.200)^{\text {** }}\end{array}$ & $\begin{array}{c}0.021 \\
(8.960)^{* * *}\end{array}$ & $\begin{array}{c}0.025 \\
(6.334)^{* * *}\end{array}$ & $\begin{array}{c}0.030 \\
(6.175)^{* * * *}\end{array}$ & $\begin{array}{c}0.048 \\
(5.034)^{* * * *}\end{array}$ \\
\hline Age & $\begin{array}{c}-0.004 \\
(-1.039)\end{array}$ & $\begin{array}{c}-0.006 \\
(-1.529)^{*}\end{array}$ & $\begin{array}{c}-0.008 \\
(-1.805)^{* *}\end{array}$ & $\begin{array}{c}-0.006 \\
(-1.103)\end{array}$ & $\begin{array}{c}0.021 \\
(2.462)^{* *}\end{array}$ \\
\hline Ceop*Ownership & $\begin{array}{c}0.012 \\
(4.748)^{* * *}\end{array}$ & $\begin{array}{c}0.008 \\
(2.652)^{* * *}\end{array}$ & $\begin{array}{c}0.009 \\
(1.918)^{* *}\end{array}$ & $\begin{array}{c}0.010 \\
(1.890)^{* *}\end{array}$ & $\begin{array}{c}0.007 \\
(0.570)\end{array}$ \\
\hline Ceop*Ownership*Soe & $\begin{array}{c}-0.001 \\
(-0.269)\end{array}$ & $\begin{array}{c}0.003 \\
(0.687)\end{array}$ & $\begin{array}{c}0.003 \\
(0.677)\end{array}$ & $\begin{array}{c}0.005 \\
(0.948)\end{array}$ & $\begin{array}{c}0.012 \\
(1.078)\end{array}$ \\
\hline Industry & $\begin{array}{c}-3.2 \mathrm{E}-05 \\
(-0.180)\end{array}$ & $\begin{array}{c}3.1 \mathrm{E}-05 \\
(0.216)\end{array}$ & $\begin{array}{c}-7.0 \mathrm{E}-05 \\
(-0.407)\end{array}$ & $\begin{array}{l}-5.0 \mathrm{E}-05 \\
(-0.177)\end{array}$ & $\begin{array}{c}-0.00024 \\
(-0.665)\end{array}$ \\
\hline Pseudo R-squared & 0.079 & 0.091 & 0.110 & 0.132 & 0.173 \\
\hline Adjusted R-squared & 0.062 & 0.075 & 0.094 & 0.117 & 0.158 \\
\hline Quasi-LR statistic & 73.676 & 118.160 & 149.770 & 165.938 & 138.412 \\
\hline Prob (Quasi-LR stat) & 0.000 & 0.000 & 0.000 & 0.000 & 0.000 \\
\hline
\end{tabular}


CEO Power, Corporate Risk-Taking, and the Role of Institutional...

Table 8. fitness results of model 3. (dependent variable: systematic risk)

\begin{tabular}{|c|c|c|c|c|c|}
\hline Quintile regression & $\% 10$ & $\% 30$ & $\% 50$ & $\% 70$ & $\% 90$ \\
\hline Variable & $\begin{array}{c}\text { Coefficient } \\
(\mathrm{t}- \\
\text { Statistic) }\end{array}$ & $\begin{array}{c}\text { Coefficient } \\
(\text { t- } \\
\text { Statistic) }\end{array}$ & $\begin{array}{c}\text { Coefficient } \\
\text { (t- } \\
\text { Statistic) }\end{array}$ & $\begin{array}{c}\text { Coefficient } \\
(t- \\
\text { Statistic) }\end{array}$ & $\begin{array}{c}\text { Coefficient } \\
(t- \\
\text { Statistic) }\end{array}$ \\
\hline $\mathrm{C}$ & $\begin{array}{c}3.947 \\
(6.962)^{* * *} \\
\end{array}$ & $\begin{array}{c}3.725 \\
(7.873)^{* * *} \\
\end{array}$ & $\begin{array}{c}4.235 \\
(10.758)^{* * *} \\
\end{array}$ & $\begin{array}{c}3.765 \\
(6.607)^{* * *} \\
\end{array}$ & $\begin{array}{c}3.400 \\
(2.607)^{* * *} \\
\end{array}$ \\
\hline Ceop & $\begin{array}{c}-0.087 \\
(-1.827)^{* *}\end{array}$ & $\begin{array}{c}-0.097 \\
(-3.041)^{\text {*** }}\end{array}$ & $\begin{array}{c}-0.080 \\
(-2.934)^{* * * *}\end{array}$ & $\begin{array}{c}-0.091 \\
(-2.964)^{\text {**** }}\end{array}$ & $\begin{array}{c}-0.171 \\
(-3.411)^{* * *}\end{array}$ \\
\hline Board size & $\begin{array}{c}-0.024 \\
(-0.316) \\
\end{array}$ & $\begin{array}{c}-0.005 \\
(-0.065)\end{array}$ & $\begin{array}{c}-0.034 \\
(-0.661)\end{array}$ & $\begin{array}{c}0.018 \\
(0.254) \\
\end{array}$ & $\begin{array}{c}-0.030 \\
(-0.199) \\
\end{array}$ \\
\hline Indp. Directors & $\begin{array}{c}0.019 \\
(0.061)\end{array}$ & $\begin{array}{c}0.081 \\
(0.466)\end{array}$ & $\begin{array}{c}0.023 \\
(0.168)\end{array}$ & $\begin{array}{c}-0.039 \\
(-0.230)\end{array}$ & $\begin{array}{c}-0.283 \\
(-0.558)\end{array}$ \\
\hline $\begin{array}{c}\text { Ownership } \\
\text { concentration }\end{array}$ & $\begin{array}{c}-0.893 \\
(-3.815)^{* * *}\end{array}$ & $\begin{array}{c}-0.859 \\
(-5.168)^{* * *}\end{array}$ & $\begin{array}{c}-0.654 \\
(-5.126)^{* * *}\end{array}$ & $\begin{array}{c}-0.462 \\
(-2.824)^{* * *}\end{array}$ & $\begin{array}{c}-0.239 \\
(-0.562)\end{array}$ \\
\hline $\begin{array}{l}\text { Management } \\
\text { shareholding }\end{array}$ & $\begin{array}{c}0.006 \\
(2.591)^{* *}\end{array}$ & $\begin{array}{c}0.003 \\
(2.178)^{* * *}\end{array}$ & $\begin{array}{c}0.002 \\
(1.784)^{* *}\end{array}$ & $\begin{array}{l}5.4 \mathrm{E}-05 \\
(0.036)\end{array}$ & $\begin{array}{c}0.002 \\
(0.148)\end{array}$ \\
\hline ROA & $\begin{array}{c}-0.012 \\
(-2.219)^{* *}\end{array}$ & $\begin{array}{c}-0.014 \\
(-3.624)^{\text {*** }}\end{array}$ & $\begin{array}{c}-0.011 \\
(-2.433)^{* *}\end{array}$ & $\begin{array}{c}-0.007 \\
(-2.172)^{* * *}\end{array}$ & $\begin{array}{c}-0.013 \\
(-1.586)^{*}\end{array}$ \\
\hline Leverage & $\begin{array}{c}0.492 \\
(1.391)^{*}\end{array}$ & $\begin{array}{c}0.434 \\
(2.006)^{* *} \\
\end{array}$ & $\begin{array}{c}0.295 \\
(1.577)^{*} \\
\end{array}$ & $\begin{array}{c}0.551 \\
(2.755)^{* * *} \\
\end{array}$ & $\begin{array}{c}0.834 \\
(2.763)^{* * *} \\
\end{array}$ \\
\hline Size & $\begin{array}{c}-0.040 \\
(-1.264)\end{array}$ & $\begin{array}{c}-0.043 \\
(-1.458)^{*}\end{array}$ & $\begin{array}{c}-0.053 \\
(-2.523)^{* *} \\
\end{array}$ & $\begin{array}{c}-0.071 \\
(-3.605)^{* * *}\end{array}$ & $\begin{array}{c}-0.050 \\
(-1.166) \\
\end{array}$ \\
\hline CAPEX & $\begin{array}{c}0.898 \\
(4.054)^{* * *} \\
\end{array}$ & $\begin{array}{c}0.120 \\
(0.589) \\
\end{array}$ & $\begin{array}{c}-0.230 \\
(-1.177)\end{array}$ & $\begin{array}{c}-0.298 \\
(-0.943) \\
\end{array}$ & $\begin{array}{c}0.046 \\
(0.070)\end{array}$ \\
\hline Cash Flows & $\begin{array}{c}-0.112 \\
(-0.964)\end{array}$ & $\begin{array}{c}-0.129 \\
(-0.665)\end{array}$ & $\begin{array}{c}-0.064 \\
(-0.249)\end{array}$ & $\begin{array}{c}0.123 \\
(1.731)^{*}\end{array}$ & $\begin{array}{c}0.127 \\
(0.392)\end{array}$ \\
\hline Market-to-Book & $\begin{array}{c}0.047 \\
(0.505)\end{array}$ & $\begin{array}{c}0.079 \\
(2.124)^{\text {*** }}\end{array}$ & $\begin{array}{c}0.087 \\
(1.941)^{* *}\end{array}$ & $\begin{array}{c}0.120 \\
(2.318)^{\text {** }}\end{array}$ & $\begin{array}{c}0.436 \\
(4.229)^{* * *}\end{array}$ \\
\hline Age & $\begin{array}{c}-0.324 \\
(-4.286)^{\text {*** }}\end{array}$ & $\begin{array}{c}-0.155 \\
(-2.593)^{* *}\end{array}$ & $\begin{array}{c}-0.120 \\
(-2.307)^{* *}\end{array}$ & $\begin{array}{c}-0.032 \\
(-0.607)\end{array}$ & $\begin{array}{c}0.124 \\
(0.763)\end{array}$ \\
\hline Ceop*Ownership & $\begin{array}{c}0.151 \\
(2.658)^{* * *} \\
\end{array}$ & $\begin{array}{c}0.137 \\
(2.307)^{* *} \\
\end{array}$ & $\begin{array}{c}0.126 \\
(3.456)^{* * *} \\
\end{array}$ & $\begin{array}{c}0.111 \\
(2.673)^{* * *} \\
\end{array}$ & $\begin{array}{c}-0.023 \\
(-0.402) \\
\end{array}$ \\
\hline Ceop*Ownership*Soe & $\begin{array}{c}0.129 \\
(1.879)^{* *} \\
\end{array}$ & $\begin{array}{c}0.068 \\
(1.040) \\
\end{array}$ & $\begin{array}{c}0.030 \\
(0.642) \\
\end{array}$ & $\begin{array}{c}0.018 \\
(0.379) \\
\end{array}$ & $\begin{array}{c}0.107 \\
(1.205) \\
\end{array}$ \\
\hline Industry & $\begin{array}{c}-0.007 \\
(-1.481)^{*}\end{array}$ & $\begin{array}{c}-0.004 \\
(-1.560)^{*}\end{array}$ & $\begin{array}{c}-0.006 \\
(-3.168)^{* * *}\end{array}$ & $\begin{array}{c}-0.005 \\
(-2.213)^{* *}\end{array}$ & $\begin{array}{c}-0.008 \\
(-2.292)^{* *}\end{array}$ \\
\hline Pseudo R-squared & 0.134 & 0.131 & 0.115 & 0.080 & 0.096 \\
\hline Adjusted R-squared & 0.119 & 0.116 & 0.099 & 0.064 & 0.080 \\
\hline Quasi-LR statistic & 104.399 & 165.065 & 179.100 & 115.099 & 67.699 \\
\hline Prob (Quasi-LR stat) & 0.000 & 0.000 & 0.000 & 0.000 & 0.000 \\
\hline
\end{tabular}


Regarding the results of tables $6,7 \& 8$, it can be stated that CEO power in different quintiles has an inverse relationship with the general and systematic risk of the firms. Therefore, by having more discretion, more powerful managers adopt less risky decisions which indicate that to prove goodwill and maintain position, CEOs prefer riskier decisions which is according to Haider and Fang (2018). Institutional investors in different quintiles have an inverse relationship with general and systematic firm risk so that this inverse effect on risk is more than CEO power. Also, the less risky the firm (general and systematic risk), the stronger this inverse relation will be. Therefore, institutional investors require CEOs to adopt decisions alongside other shareholders benefits and have a monitoring role. But, the significant point is when the relationship between institutional ownership and CEO power is examined together with individual indices of the risk, because unlike the separately available relationship between the above-mentioned variables, this relationship is positive, such that, by reducing the risk of the firms under study, the extent of this relation will be amplified. It can be said that this change of behavior can be as a result of CEO influence or monitoring power of institutional investors on manager decisions. Therefore, the role of institutional investors is more important since it affects the relationship between CEO power and firm risk, i.e. institutional investors by their resources and power require CEOs to adopt important decisions which increase firm risk which is according to the implicit notion of agency theory which indicates that large shareholders have monitoring role on CEOs discipline but in spite of their influence on the relationship between CEO power and firms risk, the main negative relationship will not be altered which is according to the studies of Jhou \& Adams (2008), Haider \& Fang (2016), Haider \& Fang (2018), Nikbakht \& Taheri (2014).

One of the most important advantages of quintile regression is that it examines the dependent variable changes to an explanatory variable during several quintiles. It is worth mentioning that blue dashes-dot in the presented figures indicate quintile coefficients and red dashes indicate confidence interval for the estimator in the considered quintile. As it can be seen, the slope coefficient of quintile regressions is different in various quintiles which indicates that the dependent variable is influenced by the independent variable. for example, in figure 1, in 10\%-30\% and 70\%-90\% quintiles, the general risk is more influenced comparing CEO power and the slope coefficient of the mentioned quintiles is more than quintiles under investigation. To understand this process and the above results, the coefficient change diagram is depicted in figures 1, 2, 3 for each study model. 

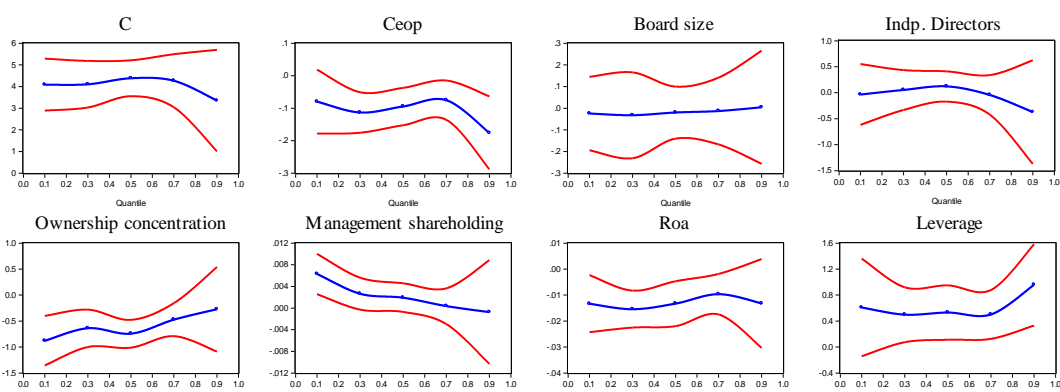

Roa

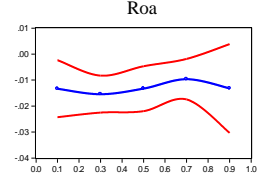

Leverage

Size

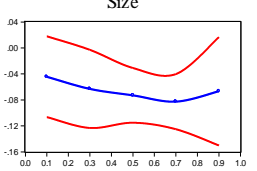

Capex

Ouantie
Cash flow
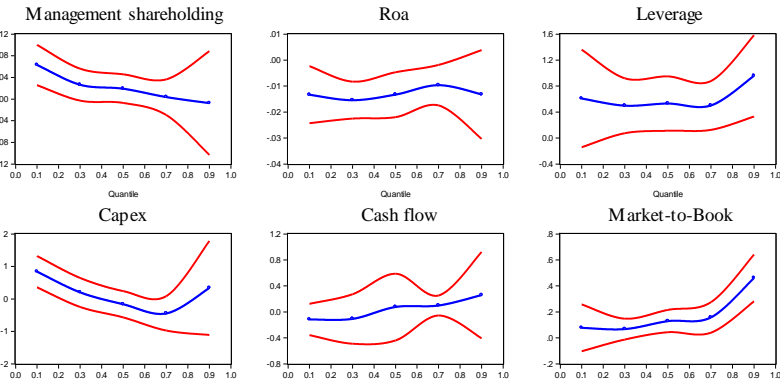

Market-to-Book

Age
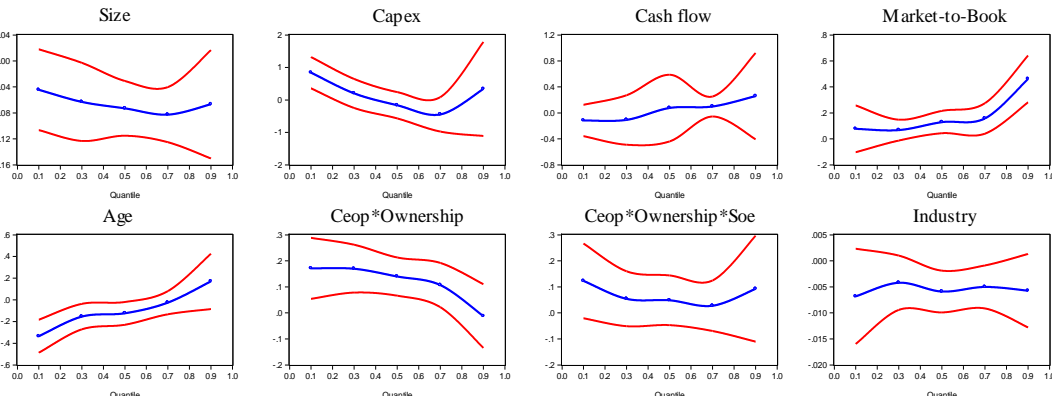

Industry

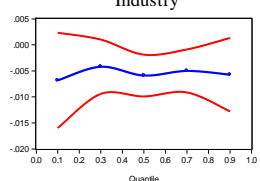

Figure 1. coefficient change of the parameters related to model1 in various quintiles.
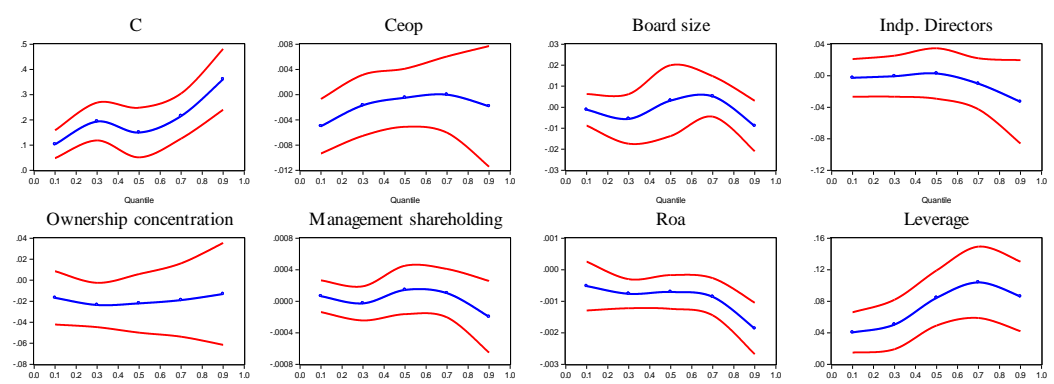

Roa
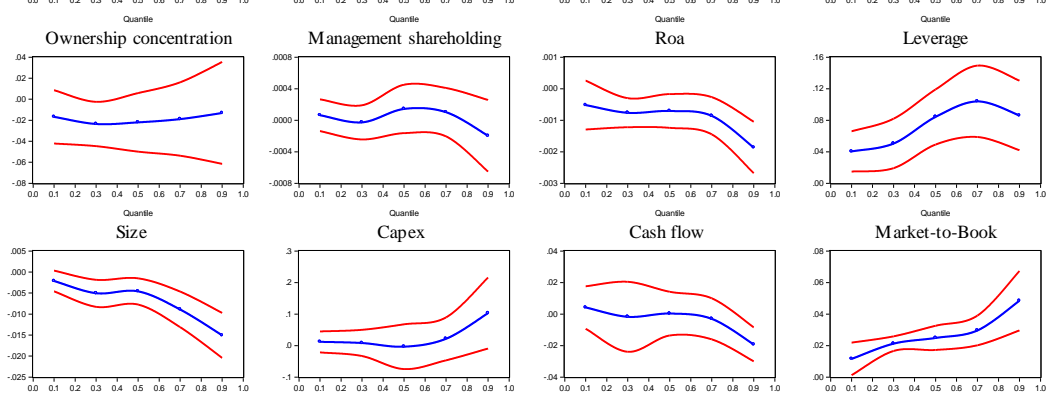

Capex
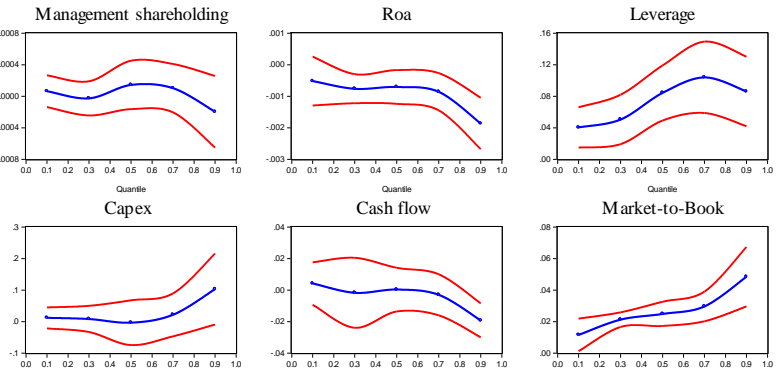

Age
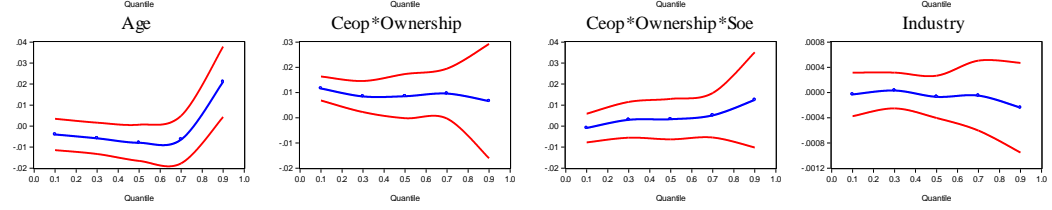

Figure 2. coefficient change of the parameters related to model 2 in various quintiles. 


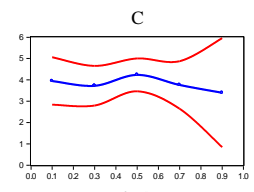

Ownership concentratio

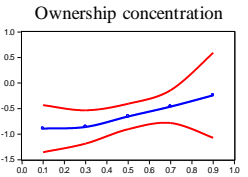

Size

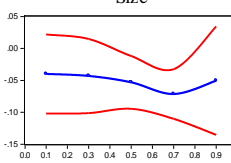

Age

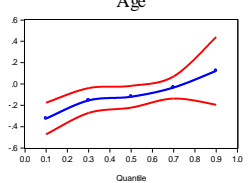

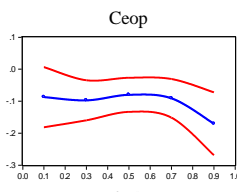

Management shareholding

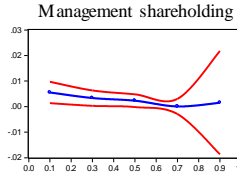

Capex

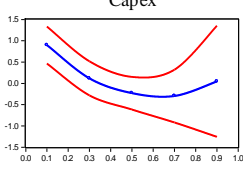

Ceop*Ownership

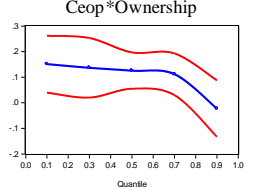

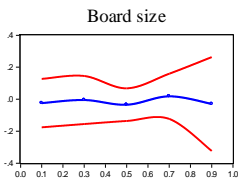

Roa

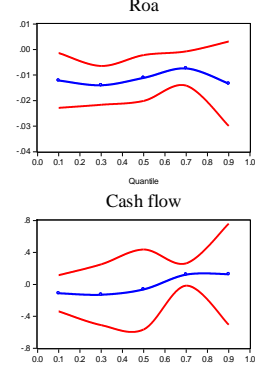

Ceop*Ownership*Soe

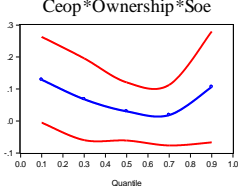

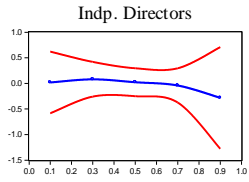

Leverage

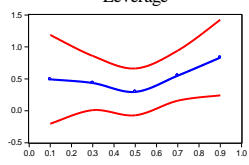

Market-to-Book

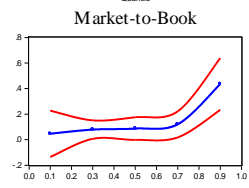

auanile
Industry

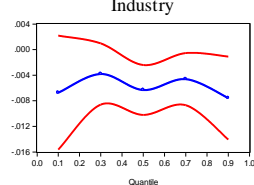

Figure 3. coefficient change of the parameters related to model 3 in various quintiles.

\section{Conclusion and discussion}

In the present study, it is attempted to investigate the relationship between CEO power and institutional ownership with the risk-taking behavior of the member firms in the Tehran stock exchange market during 2010- 2019 by using 13 key variables and principal component analysis method for defining CEO power. To clarify this issue, general, specific and systematic risk is used as the dependent variable. The quintile method is used to fit models so that users have a more clear image of the study. following results analysis, the following findings were achieved.

Generally, the present study indicates that firm risk (general and systematic) will be lower by increasing CEO power and having more powerful CEOs. It can be mentioned that since CEO efficiency is evaluated as a result of the firms under their leadership, this will indicate the importance of failure or success of a firm for managers. So it can be formulated that eager managers who like to protect their reputation are expert decision-makers, therefore they try to reduce firm risk. also, institutional ownership among investors will reduce risk. Agency theory and the monitoring role of institutional investors can be mentioned in this regard. 
While the effect of the variables is considered simultaneously, the risk will have a pronounced increase such that in the lower quintile, risk increase is more which is influenced by the two following issues:

First, Since the risk index is gained through standard deviation of the firms, It can be said that stock price is influenced by institutional owners and is more deviated. Second, managerial decisions are influenced by institutional investors which creates conflicts of interest per se, because by exerting power and influence, institutional investors affect firm strategy and the firm risk will be higher. Therefore, the above situations, both indicate institutional investors exertion of power and influence. It can be mentioned that regarding the economic and political situation of Iran, systematic risk is the most important challenge for managers and they attempt to solve this problem by adopting decisions since key variables affect general and systematic firm risk and the effect of these variables is not reliable on specific risk of the member firms of static population.

Regarding the mentioned issues, the results of this study can provide managers, investors and researchers with helpful information about the decision making process of the firms and familiarize them with the effect of these processes on firm risk. In turn, this can help managers cognitive abilities and control the effects of certain actions. Therefore, it is recommended that managers pay special attention to the results of this study. Researchers are also recommended to include more key variables in future studies and formulate CEO power accurately. By investigating the relationship between CEO power and institutional investor with the firm return, managers can also gain more accurate knowledge of the problem.

\section{Declaration of Conflicting Interests}

The authors declared no potential conflicts of interest concerning the research, authorship and, or publication of this article.

\section{Funding}

The authors received no financial support for the research, authorship and, or publication of this article. 


\section{References}

Abdul Rahman, R. \& Wan Wan, M. \& Zaki Nik S. (2011). A Panel Data Analysis On The Effects Of Independent Directors Characteristics, Ethnicity And The Level Of Risks On Discretionary Accruals In Malaysian Manufacturing Companies. AFAANZ Conference, Darwin, Australia.

Abbasi, M. \& Ahmadi, M. (2013). The Relationship between Institutional Governance-Ownership and Firm Value. management \& development process, 26(1): 191-213. (in Persian)

Ayazi, M. \& Eslami, KH. (2019). The relationship between CEO power and corporate risk-taking in listed companies in Tehran Stock Exchange. 2nd conference on new advances on science and metascience humanity sciences, Mashhad, Iran. (in Persian)

Bahrami, E. (2017). Investigation of the relationship between CEO gender and efficiency of capital allocation corporate by the risk-taking at companies listed in Tehran Stock Exchange. M.SC. Thesis in Accounting. Research and Technology Hakim Jorjani. (in Persian)

Becker, B. Cronqvist, H. \& Fahlenbrach, R. (2011). Estimating the effects of large shareholders using a geographic instrument. Journal of Financial and Quantitative Analysis, 46(4): 907-942.

Chen, D. \& Y. Zheng. (2014). CEO tenure and risk-taking. Global Business and Finance Review, 19(1): 1-27.

Eling, M. \& S. D. Marek. (2014). Corporate governance and risk-taking: Evidence from the UK and German insurance markets. Journal of Risk and Insurance, 81(3): 653-682.

Haider, J. \& H. X. Fang. (2016). Board size, ownership concentration and future firm risk. Chinese Management Studies, 10(4): 692-709.

Haider, J. \& H. X. Fang. (2018). CEO power, corporate risk-taking and role of large shareholders. Journal of Financial Economic Policy, 10(1): 55-72.

La Porta, R. Lopez-de-Silanes, F. \& Shleifer, A. (1999). Corporate ownership around the world. Journal of Finance, 54(2): 471-518.

Liu, Y. \& Jiraporn, P. (2010). The effect of CEO power on bond ratings and yields. Journal of Empirical Finance, 17(4): 744-762.

Mahmoodabadi, H. \& Zamani, Z. (2016). Investigating the Relationship between Corporate Risk-Taking and Financial Performance with Emphasis on Corporate Governance. empirical studies in financial accounting Quarterly, 13(49): 141170. (in Persian)

Malekian, E. \& Shayestehmand, H.R. (2016). The Effect of Managerial Mechanisms 
of Corporate Governance on Risk-Taking: Evidence from Tehran Stock Exchange. quarterly financial accounting journal, 7(28): 105-126. (in Persian)

Marrakchi, C. S. jean, B. \& Lucie, C. (2004). Corporate Governance and Earning management. available at www.SSRN.com/abstract=275053, (April 21, 2001).

Mc Nulty, T. Florackis, C. \& Ormrod, P. (2012). Corporate Governance and Risk: A Study of Board Structure and Process. The Management School University of Liverpool.

Nguyen, P. (2011). Corporate governance and risk-taking: Evidence from Japanese firms. Pacific-Basin Finance Journal, 19(3): 278-297.

Nikbakht M.R. Seyedi, S.A. \& Hashem Alhosseini, R. (2010). investigating the influence of board of director characteristics on the firm performance. journal of accounting advances (JAA) (journal of social sciences and humanities), 2(1): 251-270. (in Persian)

Nikbakht M.R. \& taheri, Z. (2014). Investigating the Relationship between Corporate Governance and Systematic Risk. Accounting and Auditing Review, 21(1): 109126. (in Persian)

Nikpour, M. (2014). The relation between corporate governance and financial, operational and environmental risks in companies accepted in TSE. M.Sc.Thesis in Accounting, Alzahra University. (in Persian)

Parvan, H. Ramzanpoor, E. \& gholizadeh, MH. (2017). The Study of the Impact of the Corporate Governance mechanisms on the Risk-Taking Behavior in Listed Companies of the Tehran Stock Exchange. financial monetary economics, 24(13): 124-149. (in Persian)

Pathan, S. (2009). Strong boards, CEO power and bank risk-taking. Journal of Banking \& Finance, 33(7): 1340-1350.

Serfling, M. A. (2014). CEO age and the riskiness of corporate policies. Journal of Corporate Finance, 25: 251-273.

Tootchi, M. (2015). The Impact Of Board Diversity Composition On Financial Reporting Quality And Risk In listed companies in Tehran Stock Ex. M.SC. Thesis in Accounting, Alzahra University. (in Persian)

Zou, H. \& Adams, M. B. (2008). Corporate ownership, equity risk and returns in the People's Republic of China. Journal of International Business Studies, 39: $1149-1168$. 
Iranian Journal of Finance, 2021, Vol. 6, No. 1 (Bigdlo, J.)

\section{Appendix}

The research sample companies

\begin{tabular}{|c|c|c|c|c|c|}
\hline no & Company Name & no & Company Name & no & Company Name \\
\hline 1 & Abadgaran & 37 & Khash Cement & 73 & Mehrcam Pars \\
\hline 2 & Absal & 38 & Khazar Cement & 74 & Petr. Tran \\
\hline 3 & ama & 39 & Darab Cement & 75 & Motorsazan \\
\hline 4 & S*Iran Transfo & 40 & Doroud Cement & 76 & Nasir Machine \\
\hline 5 & Iran Khodro & 41 & Soufian Cement & 77 & Behran Oil \\
\hline 6 & Iran Yasa Tire & 42 & Gharb Cement & 78 & Pars Oil \\
\hline 7 & Irka Part & 43 & Siman Fars Noe & 79 & Aluminium R. \\
\hline 8 & Bama & 44 & Shahdiran Inc & 80 & R. Mill Prod. \\
\hline 9 & Gorji Biscuit & 45 & Ghandi Cables & 81 & Nirou Moharreke \\
\hline 10 & Pars Khazar & 46 & Fars Chem. Ind & 82 & Nirou Trans \\
\hline 11 & S*Pars Khodro & 47 & Kerman Tire & 83 & Iran Carton \\
\hline 12 & Pars Minoo & 48 & Iran Refract. & 84 & Alvand Tile \\
\hline 13 & Khark Petr. & 49 & Iran Mineral P & 85 & Pars Tile \\
\hline 14 & Shazand Petr. & 50 & Iran Ferr & 86 & Saadi Tile \\
\hline 15 & Shiraz Petr. & 51 & Khavar Spring & 87 & Sina Tile \\
\hline 16 & Fanavaran Petr. & 52 & Zar Spring & 88 & Kaveh Paper \\
\hline 17 & Iran Glass Wool & 53 & S*Mobarakeh Steel & 89 & Calcimine \\
\hline 18 & I. Pegah Dairy & 54 & Khorasan Steel Co & 90 & Iran Carbon \\
\hline 19 & Kh. Pegah Dairy & 55 & Iran Board & 91 & Chimidarou \\
\hline 20 & Techinco & 56 & Isfahan Sugar & 92 & Alborz Darou \\
\hline 21 & Charkheshgar & 57 & Ghazvin Sugar & 93 & Pars Darou \\
\hline 22 & S*North Drilling & 58 & Bahman Group & 94 & Jaam Darou \\
\hline 23 & Tuka Trans. & 59 & Sahand Rubber & 95 & Osvah Pharm. \\
\hline 24 & Iran China Clay & 60 & Pars Shahab & 96 & Exir Pharm. \\
\hline 25 & Inf. Services & 61 & Pak Dairy & 97 & Jaber Hayan P. \\
\hline 26 & A. I. S. D. & 62 & Loabiran & 98 & Razak Lab. \\
\hline 27 & DPI & 63 & Iran Brake L & 99 & Zahravi Phar. \\
\hline 28 & Derakhshan Teh. & 64 & Iran M. \& P. M & 100 & Sobhan Pharm \\
\hline
\end{tabular}


CEO Power, Corporate Risk-Taking, and the Role of Institutional...

\begin{tabular}{|c|c|c|c|c|c|}
\hline 29 & I. T. Foundry & 65 & Iranian Leasing & 101 & Farabi Pharm. \\
\hline 30 & Mashad Wheel & 66 & Niromohareke M & 102 & Loghman Pharm. \\
\hline 31 & Saipa Diesel & 67 & VAMCO & 103 & Daroupakhsh \\
\hline 32 & Sepanta & 68 & Iran Tele. Co & 104 & Kowsar Pharm. \\
\hline 33 & Sarma Afarin & 69 & Bahonar Copper & 105 & Sina Darou Lab. \\
\hline 35 & Orumiyeh Cement & 70 & Iran Zinc Mines & 106 & Daroupakhash I. \\
\hline 36 & Behbahan Cement & 71 & Iran Mn. Mines & 107 & Daroupakhsh P. \\
\cline { 1 - 3 } & Tehran Cement & 72 & Iran Amlah & & \\
\cline { 1 - 3 } & & &
\end{tabular}

\section{Bibliographic information of this paper for citing:}

Bigdlo, Jamshid; Bashiri, Neda; Tehrani, Reza \& kheilkordi, Fatemeh (2022). CEO Power, Corporate Risk-Taking, and the Role of Institutional Owners: Pieces of Evidence of Tehran Stock Exchange Market and Iran Fara Bourse. Iranian Journal of Finance, 6(1), 117-141.

Copyright (C) 2022, Jamshid Bigdlo, Neda Bashiri, Reza Tehrani and Fatemeh kheilkordi

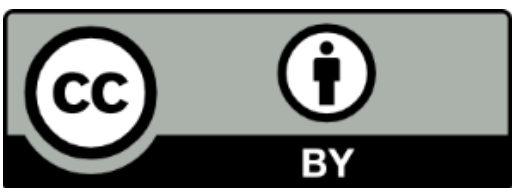

